\title{
Shedding Kinetics of Soluble Tumor Necrosis Factor (TNF) Receptors after Systemic TNF Leaking during Isolated Limb Perfusion Relevance to the Pathophysiology of Septic Shock
}

\author{
Dan Aderka, ${ }^{\star}$ Patrick Sorkine, ${ }^{\ddagger}$ Subchi Abu-Abid, ${ }^{\S}$ Dina Lev,$\S$ Arik Setton, ${ }^{\ddagger}$ Andrew P. Cope, David Wallach, \\ and Joseph Klausner§ \\ *Department of Oncology, ${ }^{\ddagger}$ Intensive Care Unit, and ${ }^{\S}$ Surgery B, Tel-Aviv Medical Center, Sackler Faculty of Medicine, Tel-Aviv \\ University, Tel-Aviv 64239, Israel; "Department of Membrane Research and Biophysics, Weizmann Institute of Science, Rehovot 76100, \\ Israel; and "Department of Microbiology and Immunology, Stanford University School of Medicine, Stanford, California 94305
}

\begin{abstract}
We examined the kinetics of shedding of the soluble TNF receptors (TNF-Rs) in response to TNF leakage during isolated limb perfusion procedures and correlated them to the resulting hemodynamic effects.

Shedding of the TNF-Rs started 7 min after TNF leakage into the systemic circulation. Three waves of shedding were observed peaking at $1,8-12$, and $48-72 \mathrm{~h}$ both in vivo and in cell cultures. The soluble receptors prolonged the half-life of TNF in the systemic circulation to 2.5-6 h. Excess shedding of the p75 compared with p55 TNF-Rs was noted during the first wave. The amount and speed of shedding of the p75 TNF-Rs were proportional to the serum TNF levels $(P<$ 0.001). A maximal shedding capacity was attained only during the first wave of shedding, at TNF concentrations of $\sim 1.5 \mathrm{ng} / \mathrm{ml}$. Above this level, the linearity between TNF and its soluble receptors was lost. TNF-induced hypotension coincided with the initial imbalance between the concentrations of TNF and its soluble receptors. Despite the spontaneous correction of this imbalance at 8-12 h, the hemodynamic and biochemical alterations persisted and were further aggravated at $18 \mathrm{~h}$, suggesting that other factors induced earlier by TNF are responsible for the perpetuation of the hemodynamic instability.

This study may provide the basis for a more physiological therapeutic approach to TNF neutralization in septic shock patients. (J. Clin. Invest. 1998. 101:650-659.) Key words: tumor necrosis factor • soluble tumor necrosis factor receptors • septic shock $\bullet$ isolated limb perfusion $\bullet$ cancer
\end{abstract}

\section{Introduction}

Tumor necrosis factor (TNF) has multiple biologic functions, including a pivotal role in the immune response to infection (1). It recruits and activates neutrophils $(2,3)$, macrophages (4), and lymphocytes $(5,6)$, and is responsible for compensa-

Address correspondence to Dan Aderka, M.D., Department of Oncology, Tel-Aviv Medical Center, Ichilov Hospital, 6 Weizmann Street, Tel-Aviv, 64239 Israel. Phone: 972-3-697-3485; FAX: 972-3-501-1708.

Received for publication 21 May 1997 and accepted in revised form 24 November 1997.

J. Clin. Invest.

(C) The American Society for Clinical Investigation, Inc. 0021-9738/98/02/0650/10 \$2.00

Volume 101, Number 3, February 1998, 650-659

http://www.jci.org tory hemodynamic changes (reference 7, and pp. 237-239 in reference 8 ) aimed to meet the demands imposed by systemic infections. TNF orchestrates all stages of inflammation, including recruitment of inflammatory cells, limitation of the process, and finally its termination, with repair of the inflammatory damages by promoting fibroblast growth (9) and neovascular formation (10). TNF is, therefore, a major protective cytokine.

Two distinct species of TNF surface receptors (TNF-R), ${ }^{1}$ p55 TNF-R and p75 TNF-R mediate the multiple effects of TNF on cell function (11-13). The p55 TNF-R is the main mediator of the TNF signaling to cells, whereas the p75 TNF-R, which has a secondary role in signaling, serves also for "ligand passing," i.e., for channeling TNF to the p55 TNF-R, thus facilitating its binding to it $(14,15)$. Rapid shedding of the p75 TNF-R may reduce the cell sensitivity to TNF (15), as ligand presentation to the p55 TNF-R may be severely impaired. Consequently, the intracellular signaling may be reduced. Both receptors for TNF exist also in soluble forms $(12,16,17)$, probably derived by proteolytic cleavage from the cell surface forms. These soluble receptors can compete for TNF with the cell surface receptors and thus block its bioavailability and activity $(12,13,16)$, serving as physiological attenuators of the TNF activity and safeguarding against its potential harmful effects.

Excess recombinant TNF can mimic most of the septic shock manifestations (17). Administration of its inhibitors, the soluble TNF-Rs (sTNF-Rs) (11-13), could protect animals if administered within the first $3 \mathrm{~h}$ of a lethal endotoxic or gramnegative bacteremic insult (18-21). However, treatment of septic shock patients with TNF inhibitors resulted in inconclusive results: while the p75 TNF-R (22) and anti-TNF antibody increased mortality rate (23), the p55 TNF-R reduced it (24, $25)$. At this stage, it was realized that there is a lack of information regarding the in vivo interactions among TNF, its soluble receptors, and the resulting hemodynamic changes in human sepsis.

We were granted a unique opportunity to clarify this issue in cancer patients undergoing isolated limb perfusion (ILP) with TNF (26-29). At high-flow limb perfusion rates, large amounts of TNF leak into the systemic circulation, inducing shedding of the TNF-Rs (30). Taking advantage of this phenomenon, we correlated the hemodynamic parameters during this procedure to the simultaneous changes in the serum concentrations of TNF and its soluble receptors $(28,29)$.

Since low-flow ILP proved to be as effective as the high-

1. Abbreviations used in this paper: CI, cardiac index; ILP, isolated limb perfusion; rTNF- $\alpha$, recombinant TNF- $\alpha$; sTNF-R, soluble TNF-R; SVR, systemic vascular resistance; TNF-R, TNF receptor. 
flow procedure in promoting tumor regression but with remarkably fewer side effects (31), high-flow ILP was abandoned, and is no longer accepted as a standard procedure for ethical reasons. The unique information obtained here may serve to optimize TNF inhibition in septic patients.

\section{Methods}

Patients. 15 consecutive cancer patients gave informed consent before undergoing ILP with high dose TNF. They comprised two groups: the first group (eight patients) underwent perfusion at a high flow rate of $868 \pm 122 \mathrm{ml} / \mathrm{min}$, and the second group (seven patients) underwent perfusion at a low flow rate of $286 \pm 62 \mathrm{ml} / \mathrm{min}$. There were nine males and six females. The mean age of patients was $46.8 \mathrm{yr}$ (range 22-78) in group I and 48.8 (range 14-78) in group II. 13 patients had locally advanced soft tissue sarcomas, and 2 had metastatic malignant melanomas. All patients had indwelling arterial and pulmonary artery catheters during the ILP procedure. Cardiac output was measured by thermodilution. Arterial, central venous, and capillary wedge pressures as well as heart rate and temperature were recorded every $10 \mathrm{~min}$ before recombinant TNF administration, every $5 \mathrm{~min}$ during the procedure, and every hour thereafter up to $48 \mathrm{~h}$. Serum glucose, urea nitrogen, creatinine, electrolytes, proteins, transaminases, alkaline phosphatase, cholesterol, and bilirubin concentrations were measured before ILP and daily thereafter. Hematologic and coagulation profiles were obtained every $4 \mathrm{~h}$ during the first day of the procedure and daily thereafter. Arterial blood gases were determined every $4 \mathrm{~h}$ during the first $48 \mathrm{~h}$. Blood samples for serum TNF and sTNF-R determination were collected from the peripheral arterial catheter and stored in aliquots at $-70^{\circ} \mathrm{C}$.

The ILP was performed as described previously by Krementz et al. (32). Briefly, the main artery and vein of the perfused limb were dissected, and the collaterals were ligated. The vessels were then cannulated and connected to a pump oxygenator identical to that used for cardiopulmonary bypass. A membrane oxygenator (BOS 5; Bentley Division, Baxter Healthcare Corp., Irvine, CA) and silicone tubes were used. A tourniquet $(200-400 \mathrm{mmHg}$ ) was applied at the root of the limb to prevent leakage. During the procedure, the temperature of the perfused limb was maintained at $39^{\circ} \mathrm{C}$. Circuit priming was performed with blood and Hartmann's solution supplied with 5,000 IU of heparin. Throughout the procedure, blood gases were drawn from the arterial and venous lines of the circuit at time 0 and every $30 \mathrm{~min}$ thereafter. At the end of the procedure, the limb was rinsed twice with $1.5 \mathrm{ml}$ of $3.5 \%$ polygeline solution (degraded gelatin polypeptide infusion, Haemaccel; Behringwerke AG, Marburg, Germany), the cannulas were extracted, and blood vessels were sutured.

Systemic leakage from the perfusate was monitored by injecting radioiodinated HSA $(20 \mathrm{mCi})$ into the circuit. Radioactivity in the systemic peripheral plasma was measured continuously using a probe and a Geiger monitor placed above the precordial area. This enabled detection of minimal leakage $(<1 \%)$.

Drugs. Lyophilized recombinant TNF- $\alpha$ (rTNF- $\alpha)$, a gift from Boehringer Ingelheim (Ingelheim, Germany) ( $0.2 \mathrm{mg} / \mathrm{ampule})$, was reconstituted with $1 \mathrm{ml}$ sterile saline. rTNF- $\alpha$ was administered at a total dose of $4 \mathrm{mg}$ for the lower limb and $3 \mathrm{mg}$ for the upper limb as a bolus into the arterial line of the perfusate. Before injection of rTNF- $\alpha$, patients were administered an intravenous fluid load of $500 \mathrm{ml}$ of Ringer's Lactate solution and intravenous dopamine at a rate of $3 \mathrm{mg} /$ $\mathrm{kg} / \mathrm{min}$, in order to ensure optimal hemodynamic conditions and a high urine output.

Melphalan (Alkeran; Glaxo Wellcome Inc., Research Triangle Park, NC) was obtained as a sterile powder, and was dissolved aseptically using solvent and diluent. The dose administered was $1.1 \mathrm{mg} / \mathrm{kg}$ body wt. Melphalan was added to the perfusate $30 \mathrm{~min}$ after rTNF- $\alpha$, and the perfusion was continued for an additional $60 \mathrm{~min}$.

$T N F$ determination. Serum TNF was assayed with an immunoenzymatic assay (TNF- $\alpha$ EASIA; Medgenix Diagnostics, Fleurus, Belgium).
Quantification of sTNF-Rs. Serum concentrations of the sTNF-Rs were determined by a two-site capture ELISA, using mouse mAbs and rabbit antisera against the sTNF-Rs as described previously (33-35).

ELISA plates (Maxisorb; Nunc, Inc., Roskilde, Denmark) were coated with $\mathrm{mAbs}$ to the soluble forms of either p 55 or p 75 TNF-Rs (36) by incubation of the plates for $2 \mathrm{~h}$ at $37^{\circ} \mathrm{C}$ with a solution of 25 $\mathrm{mg} / \mathrm{ml}$ of the antibodies in PBS containing $0.02 \% \mathrm{NaN}_{3}$. After an additional $2 \mathrm{~h}$ of incubation at $37^{\circ} \mathrm{C}$ with PBS containing $1 \%$ BSA, $0.02 \%$ $\mathrm{NaN}_{3}$ and $0.05 \%$ Tween 20 (blocking solution) to block nonspecific binding of protein, the plates were rinsed with PBS containing $0.05 \%$ Tween 20 (washing solution). Samples for testing were diluted serially in a solution containing $0.65 \mathrm{M} \mathrm{NaCl}, 10 \mathrm{mM}$ sodium phosphate buffer, $\mathrm{pH} 7.0,0.05 \%$ Tween $20,0.1 \% \mathrm{NP}-40$, and $0.02 \% \mathrm{NaN}_{3}$, then added to the plates in aliquots of $80 \mu \mathrm{l} /$ well. The plates were left at room temperature for $4 \mathrm{~h}$ and then rinsed 3 times with washing solution. Rabbit polyclonal serum against the relevant soluble receptor diluted 1:500 in blocking solution was added to the wells. After incubation overnight at room temperature, the plates were rinsed with washing solution and incubated for $2 \mathrm{~h}$ at $37^{\circ} \mathrm{C}$ with horseradish peroxidase-conjugated affinity-purified goat anti-rabbit IgG (Biomakor, Ness-Ziona, Israel). The assay was developed for 30 min using 2,2'azino-bis (3-ethylbenzthiazoline-6 sulfonic acid) (ABTS) as a substrate (Sigma Chemical Co., St. Louis, MO). The enzymatic product was determined colorimetrically at $405 \mathrm{~nm}$. Purified urine-derived soluble forms of the two receptors served as standards.

Cell lines. Human HeLa cells transfected with p75 receptor constructs (15) served for in vitro experiments. The cells were grown in DME supplemented with $10 \%$ FCS, $100 \mathrm{U} / \mathrm{ml}$ penicillin, and $100 \mathrm{mg} /$ $\mathrm{ml}$ streptomycin. The HeLa cells were plated in 24 wells (Costar Corp., Cambridge, MA) at a concentration of $2 \times 10^{5}$ cells/well. $24 \mathrm{~h}$ later, TNF at a concentration of $5 \mathrm{ng} / \mathrm{ml}$ or the anti-p55 mimetic antibody $18(50 \mathrm{mg} / \mathrm{ml})$ were added.

The supernatants were collected $30 \mathrm{~min}$ after the TNF or mimetic antibody application, and replaced with fresh medium which was collected at $1 \mathrm{~h}$ and replaced again with new medium. The cells were treated similarly at 2,3,4,6, and $8 \mathrm{~h}$. The obtained supernatants were examined for the $\mathrm{p} 75 \mathrm{TNF}-\mathrm{R}$.

$T N F$ and mimetic antibodies. The specific activity of the human TNF- $\alpha$ (Genentech Inc., South San Francisco, CA) was $5 \times 10^{7} \mathrm{U} / \mathrm{ml}$. The anti-p55 TNF-R antibody employed was 18 (at a concentration of $50 \mathrm{mg} / \mathrm{ml}$ ). This antibody is one of a panel of mAbs against the p55 TNF-R established by immunizing mice with the soluble urinary receptor (36).

\section{Results}

TNF leakage and $s T N F-R$ shedding. During high-flow limb perfusion, large amounts of TNF leaked into the systemic circulation and were detected as early as 2 min after the start of the procedure. Serum TNF concentrations $>20 \mathrm{ng} / \mathrm{ml}$ were detected throughout the $2 \mathrm{~h}$ of the limb perfusion (Fig. 1c). In contrast, after the start of low-flow limb perfusion, measurable TNF levels were characteristically $<1.5 \mathrm{ng} / \mathrm{ml}$ (Fig. $1 c$ ).

The shedding of the p55 TNF-Rs (Fig. $1 a$ ) was almost identical in low- and high-flow perfusion during the first hour. In contrast, the shedding of the p75 TNF-R was substantially higher when larger amounts of TNF leaked into the systemic circulation (Fig. 1 b). A maximal shedding capacity was noted especially for the p75 TNF-R (Fig. 1).

To exclude the possibility that the shedding is a nonspecific phenomenon induced by the traumatic operative procedure, the soluble receptor levels were monitored in two patients who underwent limb perfusion with Melphalan only. The patients had normal sTNF-Rs before the procedure, and no increase in the sTNF-R levels could be detected during or after the perfusion (not shown). 

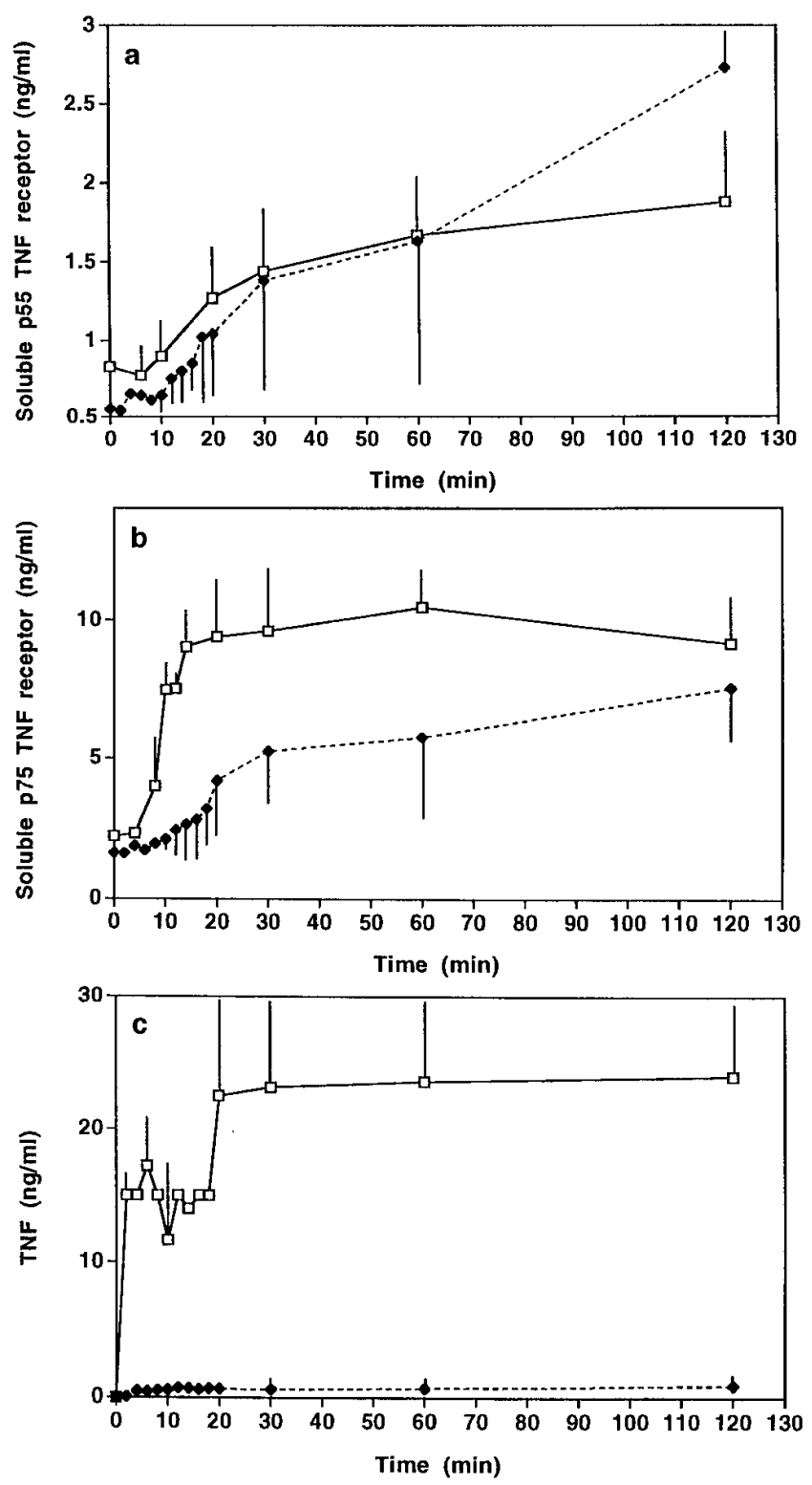

Figure 1. Shedding of p55 sTNF-Rs $(a)$ and p75 sTNF-Rs $(b)$ during the first $2 \mathrm{~h}$ of high flow (mean of six patients, open squares) and low flow rate (mean of seven patients, filled diamonds) ILP procedures. The concomitant TNF concentrations are shown in $c$.

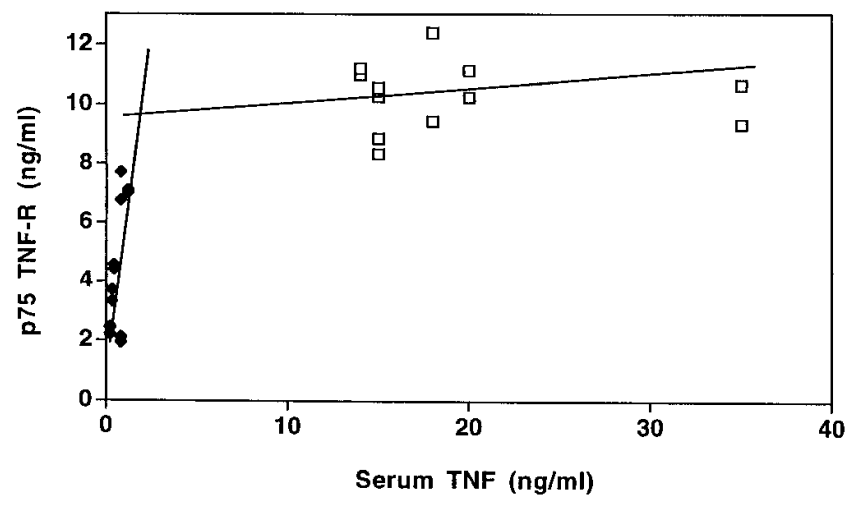

Figure 2. The correlation between p75 TNF-R (at 30 and $60 \mathrm{~min}$ ) of low- (filled diamonds) and high-flow (open squares) perfusion patients and serum TNF concentrations at $5 \mathrm{~min}$. The correlation, which was linear up to $1-1.5 \mathrm{ng} / \mathrm{ml} \mathrm{TNF}$, was lost at higher TNF concentrations, resulting in an imbalance between p75 TNF-R and TNF.

Shedding kinetics. During high-flow limb perfusion, the lag period between the start of TNF leakage into the systemic circulation and the start of sTNF-R shedding was $\sim 7 \mathrm{~min}$ (Fig. $1 b$ ). In contrast, patients who underwent low-flow procedures demonstrated a reduced and delayed peak of shedding. This observation raised the question of whether the amount of sTNF-R shedding and its speed are proportional to the serum TNF concentrations. Examination of the data obtained during low-flow perfusion revealed a positive linear correlation between serum TNF concentrations at 4 min and p75 TNF-R levels at 20-30 min after the start of the procedure $(r=0.979, P<0.001)$. In contrast, in high-flow perfusion patients, because of the higher levels of serum TNF, additional shedding of p75 TNF-R was limited by a maximal shedding capacity (Fig. $1 b$ ). This phenomenon resulted in loss of the linearity between p75 TNF-R and its ligand, generating an imbalance between them (Fig. 2). The correlation between serum TNF concentration and p55 TNF-R was not statistically significant (Table I).

The start of shedding of both receptors showed a negative correlation to the TNF concentrations: the higher the TNF level, the earlier the start of the shedding process (Table I). The correlation was almost absolute for the p75 TNF-R $(r=$ $0.98, P<0.001)$, but less pronounced for the p55 TNF-R. $(r=$ $0.83, P<0.05)$ (Table I).

Table I. Correlations between TNF-Rs and TNF during Limb Perfusion Procedures

\begin{tabular}{|c|c|c|c|c|}
\hline$x$ & $y$ & Equation & $r$ & Significance \\
\hline p55 TNF-R at $30 \mathrm{~min}$ & TNF at $4 \mathrm{~min}$ & $y=396 x-288$ & 0.735 & NS \\
\hline p75 TNF-R at $30 \mathrm{~min}$ & $\mathrm{TNF}$ at $4 \mathrm{~min}$ & $y=268 x-505$ & 0.979 & $P<0.001$ \\
\hline TNF at $4 \mathrm{~min}$ & Start of p55 TNF-R shedding (min) & $y=-0.037 x+48.7$ & 0.83 & $P<0.05$ \\
\hline TNF at $4 \mathrm{~min}$ & Start of p75 TNF-R shedding (min) & $y=-0.014 x+30.1$ & 0.983 & $P<0.001$ \\
\hline$t_{1 / 2}$ of TNF (h) & p55 TNF-R/TNF (ng/ng) & $y=1.145 x-2$ & 0.89 & $P<0.01$ \\
\hline$t_{1 / 2}$ of TNF $(h)$ & p75 TNF-R/TNF (ng/ng) & $y=5.9 x-8.37$ & 0.895 & $P<0.01$ \\
\hline $\mathrm{t}_{1 / 2}$ of TNF (h) & p55 + p75 TNF-R/TNF (ng/ng) & $y=6.345 x-10.2$ & 0.865 & $P<0.01$ \\
\hline
\end{tabular}

The correlations demonstrate the effect of TNF on the amount and speed of shedding of the TNF-Rs. Conversely, the effect of the shed receptors on the half-life of TNF in the serum is presented. 

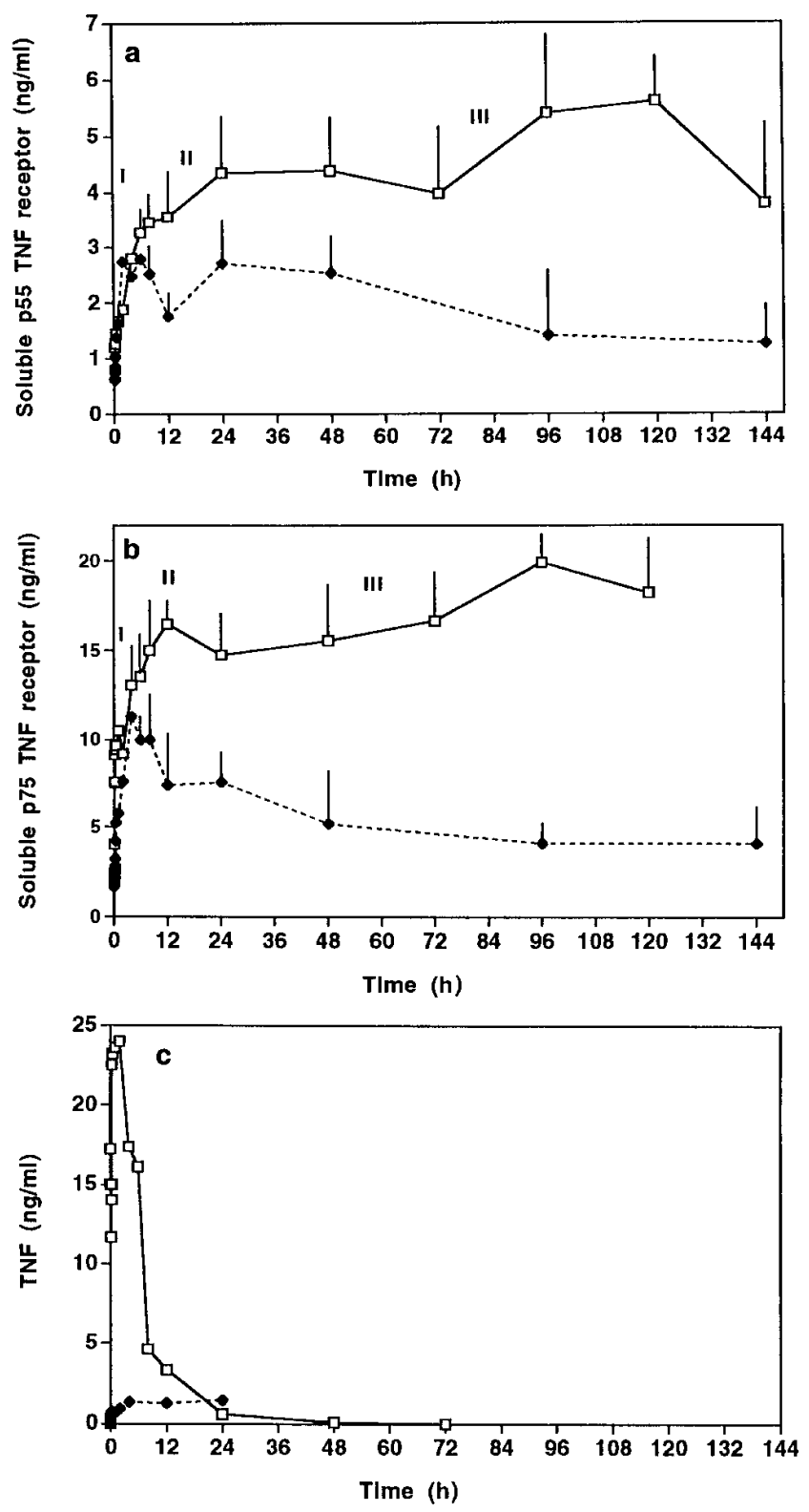

Figure 3. The course of shedding of p55 TNF-R (a) and p75 TNF-R (b) during the $6 \mathrm{~d}$ of follow-up compared with the measurable TNF systemic concentrations $(c)$. After high flow rate limb perfusions (open squares), the shedding of both receptors was triphasic: an initial 30-min peak (see also Fig. 1), a second peak at 12-24 h, and a late peak at $72-96 \mathrm{~h}$. The second peak of shedding is significantly lower as well as shorter in low flow rate limb perfusion patients (filled diamonds) and is not followed by the late, third peak of shedding. The second and third peaks of shedding are not dependent on the presence of TNF $(c)$, but are triggered by the initial, very high levels of transiently circulating TNF- $\alpha$.

The second and third waves of shedding. A second wave of shedding started at $2 \mathrm{~h}$ for both TNF-Rs (see Fig. 6, $e$ and $f$ ) in patients with excessive sTNF leakage $(>15 \mathrm{ng} / \mathrm{ml})$. This wave peaked at $24 \mathrm{~h}$ for the p55 sTNF-R and at $12 \mathrm{~h}$ for the p75 sTNF-R (Fig. $3 b$ ). A third and late wave of receptor shedding started at $72 \mathrm{~h}$ for the $\mathrm{p} 55 \mathrm{TNF}-\mathrm{R}$ and at $48 \mathrm{~h}$ for the $\mathrm{p} 75 \mathrm{TNF}-\mathrm{R}$ (Fig. 3, $a$ and $b$ ).
The late peak (at 48-72 h) of shedding of the sTNF-Rs during high-flow ILP (Fig. 3, $a$ and $b$ ) occurred despite the fact that TNF levels were no longer detectable (Fig. $3 c$ ). In contrast, in patients with low-flow ILP, who had significantly lower initial levels of circulating TNF, the shedding peaked at $\sim 4-8 \mathrm{~h}$ (see Fig. $6 e$ ), then declined, and stabilized at a lower (steady state) level between 12 and $24 \mathrm{~h}$ without inducing the third shedding wave (Fig. 3, $a$ and $b$ ).

Kinetics of shedding in vitro. To examine if the "waves" of shedding are a true and universal phenomenon, the kinetics of the sTNF-R shedding in response to TNF were examined in vitro in HeLa cells transfected with p75 constructs (15). The process of shedding had a fast, initial phase evident within 30 min from exposure to the cytokine (Fig. 4). A second phase of shedding started $3 \mathrm{~h}$ after exposure to the cytokine. An identical shedding response was observed if the cells were treated with mimetic anti-p55 antibodies (36) (Fig. 4). Further examination of the shedding kinetics revealed an additional small and late peak of shedding starting at $30 \mathrm{~h}$ after TNF activation (data not shown).

The ratio of $p 75$ to $p 55$. The ratio of $\mathrm{p} 75$ to $\mathrm{p} 55$ was very high in the first $2 \mathrm{~h}$ in high flow patients compared with low flow patients. At $\sim 4 \mathrm{~h}$, this ratio became identical in patients with low- and high-flow ILP (Fig. $5 a$ ).

The ratio of TNF-Rs to TNF. The ratio of sTNF-Rs to TNF in patients with low flow rate limb perfusion and stable hemodynamics was $>20$ during the first $12 \mathrm{~h}$ (Fig. $5 b$ ). In contrast, because of the significant TNF leakage during high-flow perfusions, the ratios of TNF-Rs to TNF (ng/ng) were characteristically $<1$ during the first $4 \mathrm{~h}$ (Fig. $5 \mathrm{~b}$ ). All of these patients experienced hemodynamic instability characterized by an increased cardiac index (CI) (Fig. $6 a$ ) and decreased systemic vascular resistance (SVR) (Fig. 6b). After the fast elimination of excess TNF (Fig. $6 f$ ) and the intensive shedding of sTNF-Rs (Fig. 3, $a$ and $b$ ) in these patients, the sTNF-Rs to TNF ratio was corrected spontaneously in $8-12 \mathrm{~h}$ (Fig. $5 \mathrm{~b}$ ). Despite this correction, the late hemodynamic deterioration at 16-18 h (Fig. 6, $a$ and $b$ ) could not be prevented. Between 8 and $18 \mathrm{~h}$, the ratio of TNF-Rs to TNF was comparable in the two groups of patients (Fig. 5 ) ), whereas at $24 \mathrm{~h}$, this ratio was

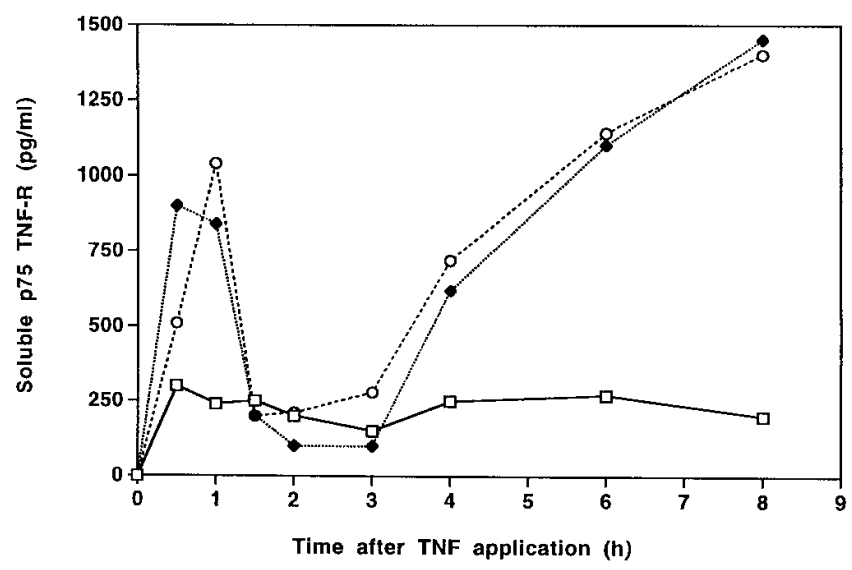

Figure 4. In vitro shedding of the p75 TNF-R by HeLa cells transfected with p75 TNF-R constructs in response to TNF- $\alpha$ (filled diamonds) and mimetic p55 TNF-R antibodies (open circles). Open squares, Control. 

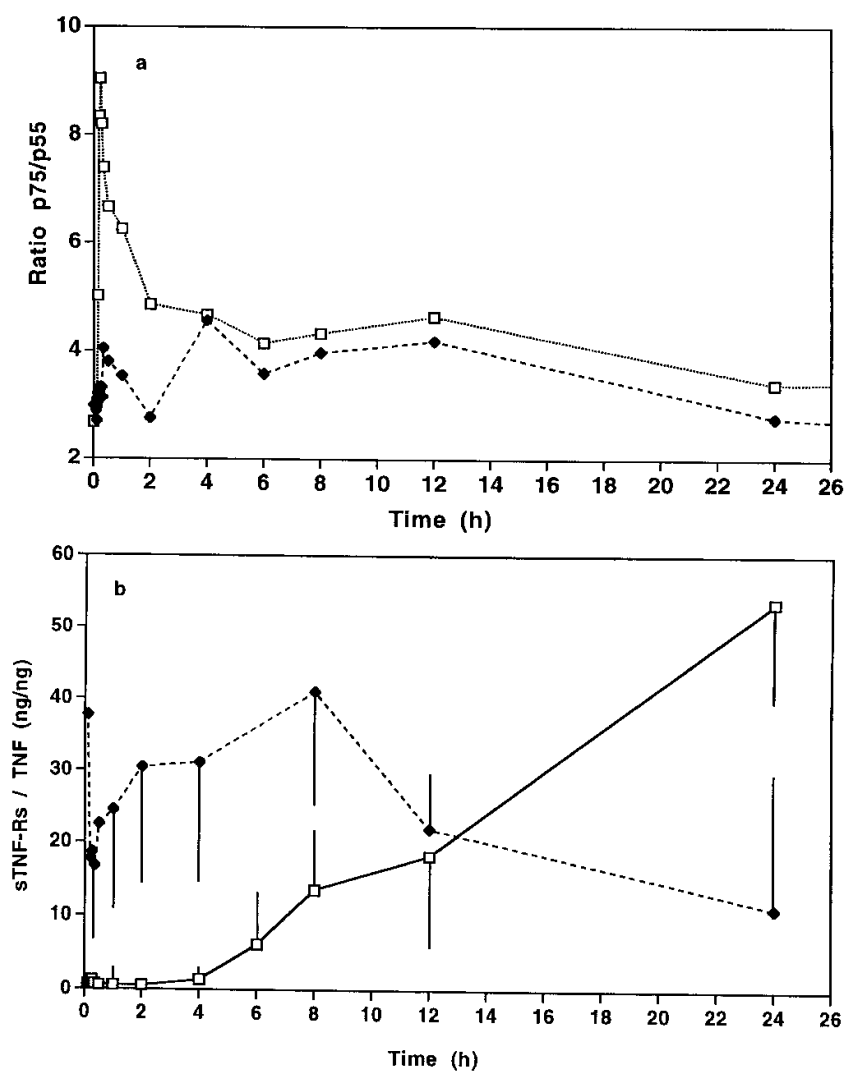

Figure 5. The ratio of p75 to p55 sTNF-Rs in low- (filled diamonds) and high-flow (open squares) ILP patients $(a)$ and the ratio of sTNF-Rs to TNF in low-flow (filled diamonds) and high-flow (open squares) limb perfusion patients during the first $24 \mathrm{~h}$ of the procedure.

reversed, to fourfold higher for the high flow compared with the low flow group (Fig. $5 b$ ). Despite this, the hemodynamic deterioration persisted (Fig. 6, $a-d$ ).

Effect of the soluble receptors on the half-life of TNF. It has been demonstrated in vitro that the TNF-Rs can stabilize the bioactivity of TNF, and that the higher the concentrations of the soluble receptors (up to a certain optimal level), the longer the half-life of the cytokine $(19,37,38)$. Whether this characteristic of the soluble receptors is limited to the artificial conditions of an in vitro experiment (37) or whether it also occurs in vivo was a pertinent question.

Fig. $6 f$ demonstrates that the TNF elimination after its leakage into the circulation with the start of the high-flow limb perfusion procedure occurred in two phases: up to $8 \mathrm{~h}$, its halflife was $2.5 \mathrm{~h}$, whereas between 8 and $24 \mathrm{~h}$, it was prolonged to $6 \mathrm{~h}$. Since the half-life elimination of free TNF is $\sim 6 \min (39)$, the considerably prolonged half-life of TNF observed here suggested a possible role for the sTNF-Rs on its prolongation. Calculation of the half-life of TNF in each patient during the different periods after the start of the perfusion procedure revealed that the half-life of TNF was correlated linearly to the ratio of sTNF-Rs $(\mathrm{ng} / \mathrm{ml})$ to TNF $(\mathrm{ng} / \mathrm{ml})$ (Table I). The higher this ratio, the longer the half-life of TNF in the systemic circulation.

In low-flow ILP patients, the TNF levels observed during the 2 -h perfusion persisted, and were stable and detectable in the circulation for up to $24 \mathrm{~h}$, demonstrating the possible effect of the soluble receptors on the half-life of relatively low levels of TNF $(<1.5 \mathrm{ng} / \mathrm{ml})$ (Fig. $6 e$ ). Whether the bound TNF is active or not could not be determined in this study.

Hemodynamic, hematologic, and metabolic changes. In patients treated with high-flow ILP, relatively high amounts of TNF leaked into the systemic circulation, and severe hemodynamic changes were observed within $1 \mathrm{~h}$. These changes were characterized by an increase in the CI (Fig. $6 a$ ) and a drop in the SVR (Fig. $6 b$ ). The systemic blood pressure, initially elevated (possibly due to the vasopressor drugs used), dropped significantly after $2 \mathrm{~h}$ (Fig. 6, $c$ and $d$ ). In contrast, in low-flow ILP patients, despite TNF leakage of up to $1.5 \mathrm{ng} / \mathrm{ml}$, the decrease in the SVR was largely compensated for by an increase in the CI, resulting in a well-preserved blood pressure (Fig. 6, $c$ and $d$ ).

No linear correlation could be found between the TNF or the p55 TNF-R concentrations and the measured hemodynamic parameters at any time. However, a significant correlation was found between the p75 TNF-R at 30 min and the SVR and $\mathrm{CI}$ at $2 \mathrm{~h}$ and SVR at $18 \mathrm{~h}$ (Table II).

Unlike the patients with low-flow ILP, those with the highflow (high TNF leakage) procedure experienced a severe drop in their platelet count (from $200,000 / \mathrm{mm}^{3}$ to $100,000 / \mathrm{mm}^{3}$ ) and more than doubling of the prothrombin time at $4 \mathrm{~h}$ (Fig. 7, $a$ and $b$ ), with a distinct increase in the fibrinogen and fibrin split products (data not shown). These patients also had a marked drop in their cholesterol levels, from $\sim 200$ to $78 \mathrm{mg} / \mathrm{ml}$ within $24 \mathrm{~h}$ (data not shown).

\section{Discussion}

The shedding of sTNF-Rs in response to TNF (30) occurs in three phases: an initial fast phase starting $\sim 7$ min after exposure to the cytokine and ending within $0.5-1 \mathrm{~h}$ (Fig. 1), a second phase starting at $\sim 2 \mathrm{~h}$ (Fig. 1), and a third and late phase starting after 72 and $48 \mathrm{~h}$ for the p55 and p75 TNF-R, respectively (Fig. 3). These waves of shedding were observed in every patient examined as well as in vitro in cells treated with TNF (Fig. 4). It is not excluded that other cytokines induced by TNF such as IL-6 (40) have a role in the induction of the second and third shedding waves.

Table II. The Correlations between the p75 TNF-R at 30 min and Hemodynamic Parameters

\begin{tabular}{|c|c|c|c|c|}
\hline$x$ & $y$ & Equation & $r$ & Significance \\
\hline p75 TNF-R at $30 \mathrm{~min}$ & SVR at $2 \mathrm{~h}$ & $y=-58.6 x+1311$ & 0.78 & $P<0.01$ \\
\hline p75 TNF-R at $30 \mathrm{~min}$ & $\mathrm{SVR}$ at $18 \mathrm{~h}$ & $y=-45.6 x+1177$ & 0.64 & $P<0.05$ \\
\hline p75 TNF-R at $30 \mathrm{~min}$ & $\mathrm{CI}$ at $1 \mathrm{~h}$ & $y=0.29 x-2.0$ & 0.77 & $P<0.01$ \\
\hline p75 TNF-R at $30 \mathrm{~min}$ & $\mathrm{CI}$ at $18 \mathrm{~h}$ & $y=0.13 x-3.14$ & 0.47 & NS \\
\hline
\end{tabular}



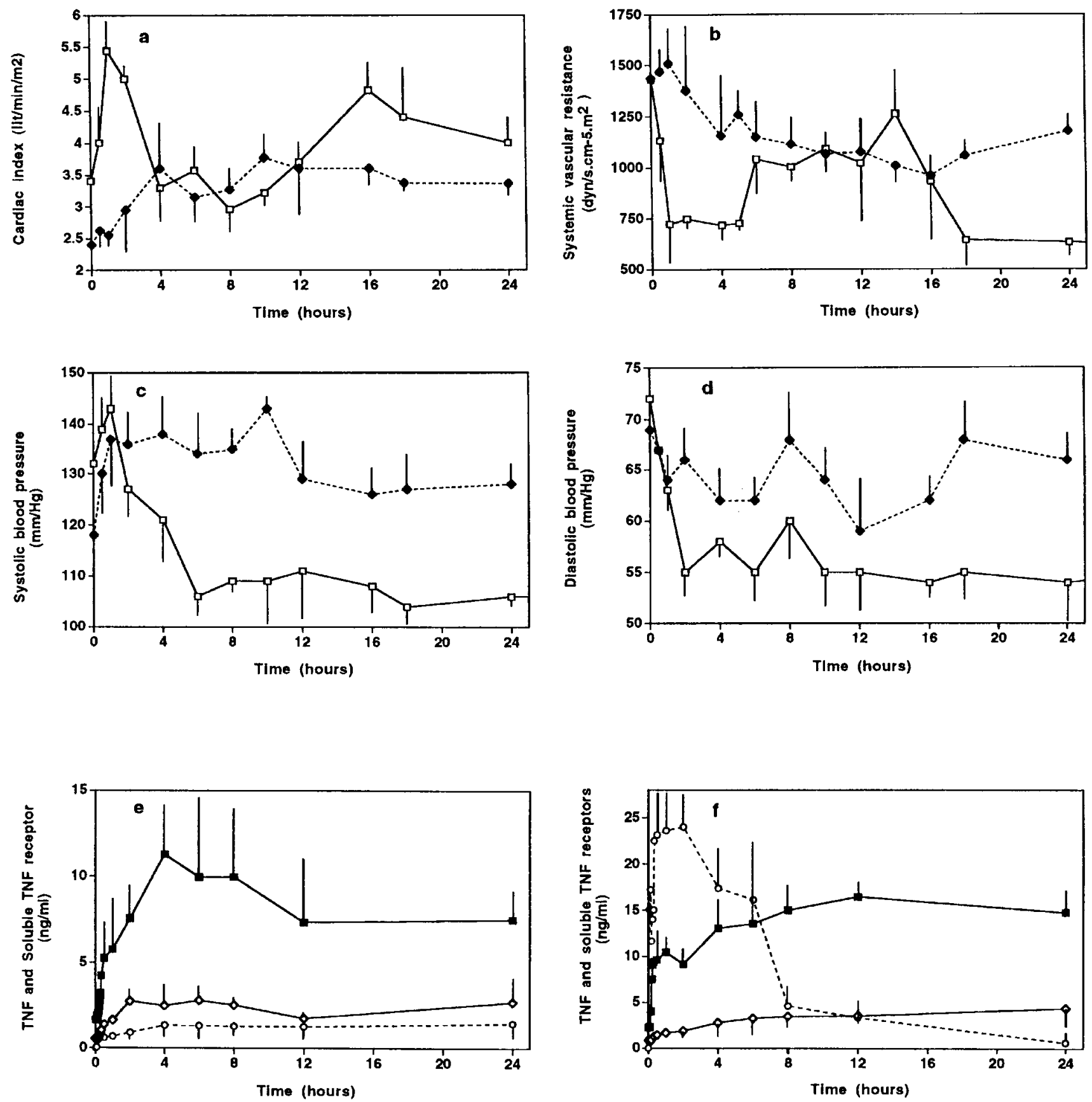

Figure 6. Comparison of hemodynamic parameters during low-flow (filled diamonds) and high-flow (open squares) limb perfusion procedures. The CI was elevated in high flow (high leakage of TNF) patients $(a)$, with significant reductions in SVR $(b)$, and systolic $(c)$ and diastolic $(d)$ blood pressure compared with low flow rate limb perfusion patients. The late deterioration (at $16 \mathrm{~h})$ in the SVR $(b)$ and the increase in the CI $(a)$ are totally unrelated to the concomitant systemic TNF- $\alpha$ concentrations $(f)$ (open circles). The TNF concentrations and the sTNF-R shedding are also presented for the low-flow $(e)$ and high-flow $(f)$ ILP patients. The marked instability in the hemodynamic parameters was generated only if the TNF levels were initially $>1.5 \mathrm{ng} / \mathrm{ml}$ (compare $e$ and $f$ ), since low flow rate patients with TNF levels below this threshold remained hemodynamically stable $(a-d)$.

The excessive p75 TNF-R shedding during the first hour was induced only by very high serum TNF concentrations (Fig. 5 a), whereas the magnitude of the p55 TNF-R shedding was similar with either low or high TNF levels (Fig. $1 a$ ). It is likely that different mechanisms are responsible for the shedding of the p55 and p75 TNF-Rs.
One of these mechanisms was possibly revealed by the in vitro observation that triggering the $\mathrm{p} 55 \mathrm{TNF}-\mathrm{R}$ with mimetic antibodies induces shedding of the p75 TNF-R. A similar mechanism is probably effective in vivo: p55 TNF-R stimulation with excess TNF could transactivate initially preferential p75 TNF-R shedding (Fig. $4 a$ ). The excessive shedding of the 

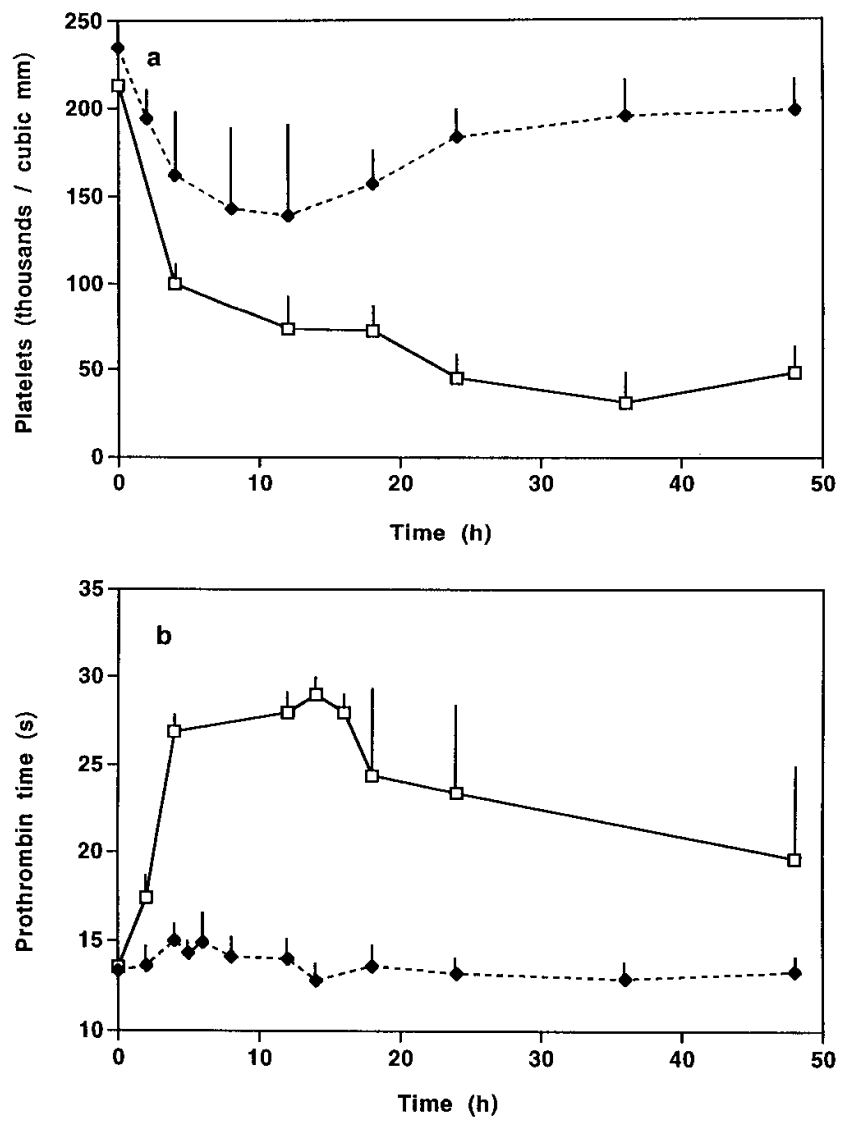

Figure 7. Hematological parameters during low-flow (filled diamonds) and high-flow (open squares) limb perfusion procedures. There is a significant reduction in the platelet number $(a)$ and a prolongation of the prothrombin time $(b)$ only in the high-flow ILP patients.

p75 TNF-R may serve as a "desensitization" mechanism aimed at reducing further TNF passing to the p55 TNF-R by the cellassociated p75 TNF-R $(14,15)$.

Release of almost all preformed cellular receptors is possibly responsible for the maximal shedding effect observed initially (Fig. 1, $a$ and $b$ ). Further shedding starting $2 \mathrm{~h}$ later (Fig. $3, a$ and $b$ ) is probably dependent on de novo receptor production. The well-controlled initial shedding phase may serve for neutralization of the excess systemic TNF, prevention of its further cellular binding, and activation and desensitization of cells to TNF itself by a transient reduction of the cell surface receptor expression (41). While the sTNF-Rs prolong the halflife of TNF in the serum, limitation of the receptor shedding to a certain maximum may facilitate the elimination of the excess, unbound TNF, with a rapid half-life of 6 min (39).

Examination of the kinetics of receptor shedding in the lowflow ILP patients disclosed that the higher the initial TNF levels at $4 \mathrm{~min}$, the more intense the shedding of the p75 TNF-R at 16-30 min. This correlation was linear and highly significant statistically (Table I). Furthermore, the higher the TNF concentrations, the faster the start of shedding of both receptors (Table I). These observations suggest the existence of a finetuning control mechanism sensing the amount of serum TNF present. This mechanism controls the speed and intensity of shedding during the first phase, to assure, probably, the appropriate TNF buffering.

Such a mechanism was suggested first by Girardin et al. (42), who found a linear correlation between low serum concentrations of TNF (up to $0.5 \mathrm{ng} / \mathrm{ml}$ ) and serum sTNF-R levels. As in this study (Fig. 2), these authors observed that when serum TNF levels exceeded a certain value $(>0.5 \mathrm{ng} / \mathrm{ml}$, in their study), the increase in the soluble receptors was no more proportional, and they suspected that the resulting imbalance, observed only during the early stage of the septic process, could be of great importance in the pathophysiology of shock (42).

In contrast to the first shedding wave, the second wave was independent of the initial TNF blood levels, and the ratio of sTNF-Rs to TNF was almost identical in both groups $8-12 \mathrm{~h}$ after the start of limb perfusion (Fig. $5 b$ and Fig. 6, $e$ and $f$ ). This was further supported by the observation that in vitro, the second shedding wave started at 3-4 h, although TNF was removed from the supernatant after the first $30 \mathrm{~min}$ (Fig. 4).

A third and late shedding phase was noted after 48-72 h only if the serum TNF concentrations increased initially (at 1-2 h) above $1.5 \mathrm{ng} / \mathrm{ml}$ (Fig. 3). This suggests that additional shedding mechanisms may be activated $48 \mathrm{~h}$ after the initial TNF leakage into the circulation, if the cytokine levels exceeded a certain threshold earlier or if an imbalance between the receptors and their ligand occurred. It is not excluded that the late waves of shedding (the second and third) are mediated partially by other cytokines induced earlier by TNF $(40,43)$.

During the first $8 \mathrm{~h}$ of the procedure, the TNF levels declined, with a half-life of $\sim 2.5 \mathrm{~h}$, and between 8 and $24 \mathrm{~h}$, with a half-life of $6 \mathrm{~h}$ (Fig. $6 f$ ). Since serum half-life of TNF was reported to be $\sim 6 \min (39)$, it is assumed that the observed prolongation of the cytokine half-life is due to its binding to the shed soluble receptors (19). An indirect confirmation of this assumption was the demonstration of a linear correlation between the actual concentrations of the sTNF-Rs and the calculated serum half-life of TNF (Table I), i.e., the higher the ratio of TNF-Rs to TNF (ng/ng), the higher the serum half-life of TNF. This TNF is probably bound to its soluble receptors and thus minimally bioavailable (19).

The ratio of sTNF-Rs to TNF was reduced markedly in the high-flow patients during the first $6 \mathrm{~h}$, reflecting the excess TNF relative to its STNF-Rs (Fig $5 b$ ). At $12 \mathrm{~h}$, the ratio of sTNF-Rs to TNF in high-flow ILP patients became identical to the ratio for low-flow ILP patients, followed at $24 \mathrm{~h}$ by higher sTNF-R to TNF ratios than in low-flow ILP patients (Fig. $5 b$ ). Clinical studies showed that septic patients who died or survived demonstrated time-related ratios of STNF-Rs to TNF similar to the high- and low-flow ILP patients, respectively $(42,44)$.

The observation that the correlation between TNF and its receptors is similar in a sterile sepsis-like condition (such as systemic TNF leakage during ILP) and a true septic process (42) suggests that the data obtained here is relevant to septic shock. The fact that no mortality was observed in our patients may be related to the absence of circulating endotoxin known to augment the lethal effects of TNF in true sepsis (45).

The hemodynamic changes observed in this study and their time course are identical to the changes observed in animal $(46,47)$ and human septic shock (see pp. 228-331 in reference 8). During low-flow ILP procedures, the TNF levels in the systemic circulation remained far below the sTNF-R concentrations (Fig. 5 b), and the hemodynamic (Fig. 6) or hematologic (Fig. 7) consequences were negligible. On the other hand, dur- 
ing the $2 \mathrm{~h}$ of high-flow ILP procedures, the systemic TNF leakage was significant, and the TNF levels were in great excess relative to the sTNF-R concentrations, resulting in a severe imbalance between TNF and its soluble receptors (Fig. 2 and Fig. $6 f$ ). Later on, at $\sim 8-12 \mathrm{~h}$, as a result of the endogenous shedding of sTNF-Rs along with the rapid elimination of unbound TNF, the balance of sTNF-Rs to TNF was regained (Fig. $5 b)$.

Concomitant with the early 4-6-h imbalance between the ligand and its receptors (Fig. $5 \mathrm{~b}$ ) and possibly related to it, a severe hemodynamic instability was observed, characterized by a drop in blood pressure and SVR (Fig. 6, b-d). Despite spontaneous correction of the balance between sTNF-Rs and TNF at $8-12 \mathrm{~h}$ (Fig. $5 \mathrm{~b}$ ) and the further reduction in serum TNF concentrations (Fig. $6 f$ ) the shock-like condition persisted in the high-flow perfusion patients (Fig. 6, $c$ and $d$ ). It was further aggravated at 16-18 h (Fig. 6, $a$ and $b$ ), suggesting that the hemodynamic and metabolic consequences of the initial imbalance between sTNF-Rs and TNF could not be reversed by its late, endogenous correction, and were actually predetermined by the initial $2-6 \mathrm{~h}$ of unopposed and unbuffered TNF bioactivity. Redundant non-TNF pathways activated early by free TNF or noncirculating, cell-bound TNF may be responsible for part of the changes in vascular tone, heart rate, and cardiac function noted at later stages (48). Part of the late and persistent hemodynamic instability recorded at 16-18 h may be mediated also by hypotensive agents, such as nitric oxide, possibly induced by TNF (49). The direct hypotensive role of TNF at this late stage may be minor, as suggested by the fact that the shock was not reversed despite the spontaneously regained balance between TNF and its endogenous inhibitors at 8-12 h (Fig. $5 b$ and Fig. 6, $b-d$ ). Obviously, at this stage, attempts to alleviate the clinical shock by additional TNF neutralization with exogenous sTNF-Rs may prove marginally effective. On the other hand, correction of the TNF-R to TNF imbalance by exogenous administration of TNF inhibitors during the early, narrow window of 4-6 h might prevent or reverse the shock condition. Several animal studies demonstrated that this window is even narrower, only $1-3 \mathrm{~h}$ after LPS administration $(20,38)$, whereas a recent clinical study showed that patient mortality rate could be reduced even if the TNF neutralization was attempted up to $12 \mathrm{~h}$ after shock initiation (25).

In conclusion, ILP with TNF provided a unique human model for studying the shedding kinetics of the sTNF-Rs and their interactions with TNF from the moment that excess TNF is released into the systemic circulation. Normally, the shedding of the natural sTNF-Rs seems to be proportional to the TNF concentrations, enabling them to buffer the cytokine bioactivity effectively (Fig. 8, curve $a$ and area $B$ ). This buffering effect allows only low levels of free TNF to be bioavailable (Fig. 8, curve $b$ ). From our data, it can be deduced that whenever the initial serum TNF levels exceed a certain threshold (between 0.5 and $1.5 \mathrm{ng} / \mathrm{ml}$ ), the linearity between TNF concentrations and those of its receptors is lost. This critical imbalance is characterized by appearance of high levels of free TNF whose unopposed bioactivity culminates in shock precipitation (Fig. 8, curve $c$ and area $C$ ). Therefore, the obvious therapeutic intervention should be administration of sTNF-Rs, anti-TNF antibodies, or dimeric Fc fusion constructs of the p55 sTNF-R (25), in an amount that will neutralize or buffer this excess, free TNF (Fig. 8, curve $c$ and area $C$ ). Complete TNF neutraliza-

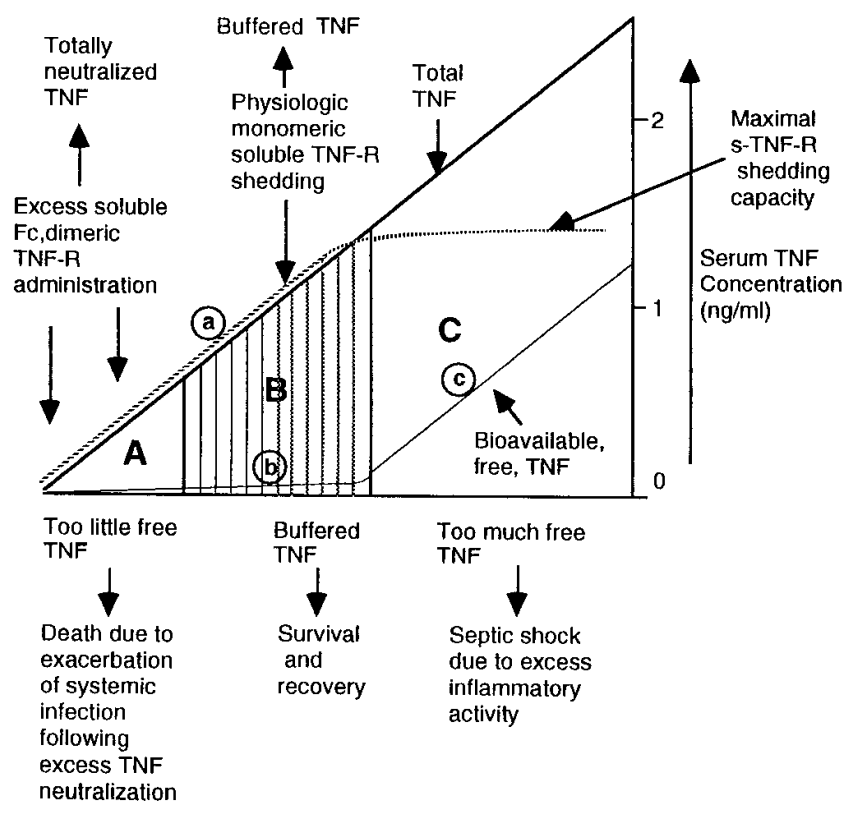

Figure 8. The possible interrelations of TNF, sTNF-Rs, and outcome in septic shock. The shedding of the sTNF-Rs is linear (curve $a$ ) up to serum TNF concentrations of $\sim 1.5 \mathrm{ng} / \mathrm{ml}$ while enabling the presence of low levels of bioavailable TNF (curve $b$ ). When the maximal shedding capacity is reached (end of area $B$ ), the imbalance between TNF and its receptors becomes increasingly pronounced and is reflected by rapidly increasing concentrations of bioavailable, free TNF (curve $c$ ). The unbuffered TNF may precipitate excess inflammatory activity and septic shock, culminating in death (area $C$ ). On the other end of the spectrum, administration of excess sTNF-Rs may result in excessive TNF neutralization, preventing the cytokine from exerting its systemic protective effects (area $A$ ).

tion (Fig. 8, area $A$ ) should be better avoided, since it may adversely affect host defenses. It may aggravate the septic condition by preventing the minute amounts of free cytokine to orchestrate the normal, protective inflammatory reactions required to overcome infection $(22,23,25,50,51)$. This conclusion is further supported by the fact that administration of p55 IgG aimed at reducing TNF to nontoxic levels while still avoiding complete TNF neutralization resulted in a $36 \%$ reduction in mortality of patients with severe sepsis (25), while total TNF neutralization was followed by an increased patient mortality (23).

This study demonstrates that after $8-12 \mathrm{~h}$, the buffering effect of the sTNF-Rs is regained (Fig. $5 b$ ), and, consequently, the TNF system returns to equilibrium (Fig. 8, area $B$ ). Attempts at additional TNF neutralization at this phase may be of little value.

Administration of the TNF inhibitors, preferably in the first $3 \mathrm{~h}$ of sepsis, although not always realistic clinically, may prove to be an effective approach to reversing septic shock. Septic patients likely to benefit from such intervention can be identified promptly (within $2-3 \mathrm{~h}$ ) by their prolonged prothrombin time and reduced platelet count (Fig. 7).

Finally, it is likely that the information presented here can be extrapolated to septic conditions, since the sTNF-R shedding, their ratio to $\mathrm{TNF}$, and the resulting hemodynamic changes after systemic TNF leakage during ILP procedures are very similar to those observed in septic shock patients $(42$, 
and see pp. 228-235 in reference 8). This data may serve to develop a more physiological and effective treatment for septic shock patients based on a better understanding of the correlation between the kinetics of the TNF system and the resulting systemic effects generated by the unbuffered cytokine.

\section{Acknowledgments}

We thank Ares Serono for providing the mAbs required for ELISA assays, and Boehringer Ingelheim for the generous gift of TNF- $\alpha$.

\section{References}

1. Grunfeld, C., and M.A. Palladino. 1990. Tumor necrosis factor: immunologic, antitumor, metabolic and cardiovascular activities. Adv. Intern. Med. 35: 45-72.

2. Shalaby, M., B. Aggarwal, E. Rinderknecht, L.P. Svedersky, B.S. Finkle, and M.A. Palladino. 1985. Activation of human polymorphonuclear neutrophil functions by interferon-gamma and tumor necrosis factors. J. Immunol. 135: 2069-2073.

3. Gamble, J., J. Harlan, S.J. Klebanoff, and M.A. Vadas. 1985. Stimulation of the adherence of neutrophils to umbilical vein endothelium by human recombinant tumor necrosis factor. Proc. Natl. Acad. Sci. USA. 82:8667-8771.

4. Philip, R., and L. Epstein. 1986. Tumor necrosis factor as immunomodulator and mediator of monocyte cytotoxicity induced by itself, gamma-interferon and interleukin-1. Nature. 323:86-89.

5. Yokota, S., T.D. Geppert, and P.E. Lipsky. 1988. Enhancement of antigen and mitogen induced human $\mathrm{T}$ lymphocyte proliferation by tumor necrosis factor. J. Immunol 140:531-536.

6. Scheurich, P., B. Thoma, U. Ucer, and K. Pfizenmaier. 1987. Immunoregulatory activity of recombinant human tumor necrosis factor (TNF)-alpha: induction of TNF receptors on human T cells and TNF-alpha-mediated enhancement of T cell responses. J. Immunol. 138:1786-1790.

7. DeMeules, J.E., F.A. Pigula, M. Mueller, S.J. Raymond, and R.L. Gamelli. 1992. Tumor necrosis factor and cardiac function. J. Trauma. 32:686-692.

8. Parrillo, J.E., M.M. Parker, C. Natanson, A.F. Suffredini, R.L. Danner, R.E. Cunnion, and F.P. Oguibene. 1990. Septic shock in humans. Advances in the understanding of pathogenesis, cardiovascular dysfunction, and therapy. Ann. Int. Med. 113:227-242.

9. Vilcek, J., V.J. Palombella, D. Henriksen-DeStefano, C. Swenson, R. Feinman, M. Hirai, and M. Tsujimoto. 1986. Fibroblast growth enhancing activity of tumor necrosis factor and its relationship to other polypeptide growth factors. J. Exp. Med. 163:632-643.

10. Frater-Schröder, M., W. Risau, R. Hallmann, P. Gautschi, and P. Böhlen. 1987. Tumor necrosis factor type $\alpha$, a potent inhibitor of endothelial cell growth in vitro is angiogenic in vivo. Proc. Natl. Acad. Sci. USA. 84:52775281 .

11. Seckinger, P., S. Isaaz, and J.M. Dayer. 1989. Purification and biologic activity of a specific tumor necrosis factor $\alpha$ inhibitor. J. Biol. Chem. 264:1196611973.

12. Engelmann, H., D. Aderka, M. Rubinstein, D. Rotman, and D. Wallach. 1989. A tumor necrosis factor-binding protein purified to homogeneity from human urine protects cells from tumor necrosis factor toxicity. J. Biol. Chem. 264:11974-11980.

13. Olsson, I., M. Lantz, E. Nilsson, C. Peetre, H. Thysell, and A. Grubb. 1989. Isolation and characterization of a tumor necrosis factor binding protein from urine. Eur. J. Haematol. 42:270-275.

14. Tartaglia, A.T., D. Pennica, and D.V. Goeddel. 1993. Ligand passing: the 75-kDa tumor necrosis factor (TNF) receptor recruits TNF for signaling by the 55-kDa TNF receptor. J. Biol. Chem. 268:18542-18548.

15. Bigda, J., I. Beletsky, C. Brakebusch, Y. Varfolomeev, H. Engelmann, J. Bigda, H. Holtmann, and D. Wallach. 1994. Dual role of the p75 tumor necrosis factor (TNF) receptor in TNF cytotoxicity. J. Exp. Med. 180:445-460.

16. Engelmann, H., D. Novick, and D. Wallach. 1990. Two tumor necrosis factor binding proteins purified from human urine. J. Biol. Chem. 265:15311536.

17. Tracey, K.J., B. Beutler, F.L. Lowry, J. Merryweather, S. Wolpe, I.W. Milsark, R.J. Hariri, T.J. Fahey, A. Zentella, J.D. Albert, et al. 1986. Shock and tissue injury induced by recombinant human cachectin. Science. 234:470-474.

18. Tracey, K.J., Y. Fong, D.J. Hesse, K.R. Manogue, A.T. Lee, G.C. Kuo, S.F. Lowry, and A. Cerami. 1987. Anti-cachectin/TNF monoclonal antibodies prevent septic shock during lethal bacteraemia. Nature. 330:662-664

19. Mohler, K.M., D.S. Torrance, C.A. Smith, R.G. Goodwin, K.E. Stremler, V.F. Fung, H. Madani, and M.B. Widmer. 1993. Soluble tumor necrosis factor (TNF) receptors are effective therapeutic agents in lethal endotoxemia and function simultaneously as both TNF carriers and TNF antagonists. J. Immunol. 151:1548-1561.
20. Ashkenazi, A., S.A. Marsters, D.J. Capon, S.M. Chamow, I.S. Figari, D. Pennica, D.V. Goeddel, M.A. Palladino, and D.H. Smith. 1991. Protection against endotoxic shock by a tumor necrosis factor immunoadhesin. Proc. Natl. Acad. Sci. USA. 88:10535-10539.

21. Lesslauer, W., H. Tabuchi, R. Gentz, M. Brockhaus, E.J. Schlaeger, G. Grau, P.F. Piguet, P. Pointaire, P. Vassalli, and H. Loetscher. 1991. Recombinant soluble tumor necrosis factor receptor proteins protect mice from lipopolysaccharide-induced lethality. Eur. J. Immunol. 21:2883-2886.

22. Fisher, C.J., Jr., J.M. Agosti, S.M. Opal, S.F. Lowry, R.A. Balk, J.C Sadoff, E. Abraham, R.M. Schein, and E. Benjamin. 1996. Treatment of septic shock with tumor necrosis factor receptor:Fc fusion protein. The soluble TNF Receptor Sepsis Study Group. N. Engl. J. Med. 334:1697-1702.

23. Abraham, E., R. Wunderink, H. Silverman, T.M. Perl, S. Nasraway, H. Levy, R. Bone, R.P. Wenzel, R. Balk, R. Allred, et al. 1995. Efficacy and safety of a monoclonal antibody to human tumor necrosis factor alpha in patients with sepsis syndrome: a randomized, controlled, double blind, multicenter clinical trial. JAMA (J. Am. Med. Assoc.) 273:934-941.

24. Kaul, M., J. Eiselstein, J. Kempeni, and L. Daum. 1996. TNF neutralization in sepsis guided by IL-6 serum levels. Eur. Cytokine Netw. 7:283. (Abstr.)

25. Abraham, E., M.P. Glauser, T. Butler, J. Garbino, D. Gelmont, P.F. Laterre, K. Kudsk, H.A. Bruining, C. Otto, E. Tobin, et al. 1997. p55 Tumor necrosis factor receptor fusion protein in the treatment of patients with severe sepsis and septic shock. A randomized controlled multicenter trial. Ro 45-2081 study group. JAMA (J. Am. Med. Assoc.). 277:1531-1538.

26. Lienard, D., P. Ewalenko, J.J. Delmotte, N. Renard, and R.J. Lejeune. 1992. High-dose recombinant tumor necrosis factor alpha in combination with interferon gamma and melphalan in isolation perfusion of the limbs for melanoma and sarcoma. J. Clin. Oncol. 10:52-60.

27. Eggermont, A.M.M., D. Lienard, H. Schraffordt-Koops, and F. Rosenkaimer, and F.J. Lejeune. 1993. Treatment of irresectable soft tissue sarcomas of the limb by isolation perfusion with high dose TNF $\alpha$ in combination with interferon- $\gamma$ and melphalan. In W. Fiers and W.A Buurman, editors. Tumor Necrosis Factor: Molecular and Cellular Biology and Clinical Relevance. S. Karger AG, Basel. 239-243.

28. Eggimann, P., R. Chiolero, P.G. Chassot, D. Lienard, J. Gerain, and F. Lejeune. 1995. Systemic and hemodynamic effects of recombinant tumor necrosis factor alpha in isolation perfusion of the limbs. Chest. 107:1047-1082.

29. Yang, J.C., D.L. Fraker, A.K. Thom, H.I. Pass, and S.A. Rosenberg. 1995. Isolation perfusion with tumor necrosis factor-alpha, interferon gamma and hyperthermia in the treatment of localized and metastatic cancer. Recent Results Cancer Res. 138:161-166.

30. Lantz, M., S. Malik, M. Slevin, and I. Olsson. 1990. Infusion of tumor necrosis factor (TNF) causes an increase in circulating TNF-binding protein in humans. Cytokine. 2:402-406.

31. Sorkin, P., S. Abu-Abid, D. Lev, M. Gutman, D. Aderka, P. Halpern, A Setton, N. Kudlic, J. Bar-On, V. Rudich, et al. 1995. Systemic leakage and side effects of tumor necrosis factor $\alpha$ administered via isolated limb perfusion can be manipulated by flow rate adjustment. Arch. Surg. 130:1079-1084.

32. Krementz, E.T., R.D. Cartger, C.N. Sutherland, and I. Hutton. 1977. Chemotherapy of sarcomas of the limbs in regional perfusion. Ann. Surg. 185: $555-564$.

33. Aderka, D., H. Engelmann, V. Hornick, Y. Skornick, Y. Levo, D. Wallach, and G. Kushtai. 1991. Increased serum levels of soluble receptors for tumor necrosis factor in cancer patients. Cancer Res. 51:5602-5607.

34. Aderka, D, A.J. Wysenbeek, H. Engelmann, A.P. Cope, F. Brennan, Y. Molad, V. Hornik, Y. Levo, R.N. Maini, M. Feldmann, and D. Wallach. 1993. Correlation between serum levels of soluble tumor necrosis factor receptor and disease activity in systemic lupus erythematosus. Arthritis Rheum. 36:11111120.

35. Cope, A.P., D. Aderka, M. Doherty, H. Engelmann, D. Gibbons, A. Jones, M.F. Brennan, R.N. Maini, D. Wallach, and M. Feldmann. 1992. Increased levels of soluble tumor necrosis factor receptors in the sera and synovial fluid of patients with rheumatic diseases. Arthritis Rheum. 35:1160-1169.

36. Engelmann, H., H. Holtmann, C. Brakebusch, Y. Shemer-Avni, I. Sarov, Y. Nophar, E. Hadas, O. Leitner, and D. Wallach. 1990. Antibodies to a soluble form of a tumor necrosis factor (TNF) have TNF-like activity. J. Biol. Chem. 265:14497-14504.

37. Aderka, D., H. Engelmann, Y. Maor, C. Brakebusch, and D. Wallach. 1992. Stabilization of the bioactivity of tumor necrosis factor by its soluble receptors. J. Exp. Med. 175:323-329.

38. De Groote, D., G.E. Grau, I. Dehart, and P. Franchimont. 1993. Stabilisation of functional tumor necrosis factor- $\alpha$ by its soluble TNF receptors. Eur. Cytokine Netw. 4:359-362.

39. Beutler, B. I.W. Milsark, and A Cerami. 1985. Cachectin/tumor necrosis factor: production, distribution and metabolic fate in vivo. J. Immunol. 135: 3972-3977.

40. Tilg, H., E. Trehu, M.B. Atkins, C.A. Dinarello, and J.W. Mier. 1994 Interleukin-6 (IL-6) as an anti-inflammatory cytokine: induction of circulating IL-1 receptor antagonist and soluble tumor necrosis factor receptor p55. Blood. 83:113-118.

41. Wallach, D. 1984. Preparations of lymphotoxin induce resistance to their own cytotoxic effect. J. Immunol. 132:2464-2469. 
42. Girardin, E., P. Roux-Lombard, G.E. Grau, P. Suter, H. Gallati, and J.M. Dayer. 1994. Imbalance between TNF $\alpha$ and soluble TNF receptor concentrations in severe meningococcaemia. The J5 Study Group. Immunology. 76: $20-23$

43. Aderka, D., H. Engelmann, and D. Wallach. 1993. Soluble TNF receptors in health and disease. In Tumor Necrosis Factor: Molecular and Cellular Biology and Clinical Relevance. W. Fiers and W.A. Buurman, editors. S. Karger AG, Basel. 191-198.

44. Schroder, J., F. Stuber, H. Gallati, F.U. Schade, and B. Kremer. 1995. Pattern of soluble TNF receptors I and II in sepsis. Infection. 23:143-148.

45. Rothstein, J.L., and H. Schreiber. 1988. Synergy between tumor necrosis factor and bacterial products causes hemorrhagic necrosis and lethal shock in normal mice. Proc. Natl. Acad. Sci. USA. 85:607-611.

46. Natanson, C., W.D. Hoffman, A.F. Suffredini, P.Q. Eichacker, and R.L. Danner. 1994. Selected treatment strategies for septic shock on proposed mechanisms of pathogenesis. Ann. Int. Med. 120:771-783.

47. Natanson, C., R.L. Eichenholz, P.Q. Danner, G.C. Hoffman, G.C. Kuo,
S.M. Banks, T.J. MacVittie, and J.E. Parrillo. 1989. Endotoxin and TNF challenges in dog simulate the cardiovascular profile of human septic shock. J. Exp. Med. 169:823-832.

48. Suffredini, A.F., D. Reda, S.M. Banks, M. Tropea, J.M. Agosti, and R. Miller. 1995. Effects of recombinant dimeric TNF receptor on human inflammatory responses following intravenous endotoxin administration. J. Immunol. 155:5038-5045

49. Killbourn, R.G., S.S. Gross, A. Jubran, J. Adams, O.W. Griffith, R Levi, and R.F. Lodato. 1990. $N G$-methyl-L-arginine inhibits tumor necrosis factor-induced hypotension: implications for the involvement of nitric oxide. Proc. Natl. Acad. Sci. USA. 87:3629-3632.

50. Echtenacher, B., W. Falk, D.N. Mannel, and P.H. Krammer. 1990. Requirement of endogenous tumor necrosis factor/cachectin for recovery from experimental peritonitis. J. Immunol. 145:3762-3766.

51. Bagby, G.J., K.J. Plessala, L.A. Wilson, J.J. Thompson, and S. Nelson. 1991. Divergent efficacy of antibody to tumor necrosis factor- $\alpha$ in intravascular and peritonitis models of sepsis. J. Infect. Dis. 163:83-88. 